\title{
The comparison of postural balance in elderly active, sedentary and with vestibulopathy
}

\section{A comparação do equilíbrio postural em idosos ativos, sedentários e com vestibulopatia}

\author{
Marcio Rogério de Oliveira', Luana da Silva Matos², Paula Thamirys Chaves Simon², Rubens Alexandre da Silva Jr², \\ Viviane de Souza Pinho Costa ${ }^{3}$
}

Universidade Norte do Paraná (UNOPAR), Londrina, PR, Brazil.

\begin{abstract}
Introduction: To be sedentary and have any disease with regard to vestibular pathology can compromise the performance of the postural control and increases the risk of falls. Objective: This study aimed to compare the postural control of elderly active, sedentary and vestibular pathology. Methods: The sample consisted of 45 elderly separated according to their current health condition: elderly active, sedentary and with vestibulopathy. The postural balance tests were performed in bipedal support, eyes open and the variables measured by the force platform were the center of pressure and average speeds of postural sway in the directions, anteroposterior $(\mathrm{A} / \mathrm{P})$ and medial-lateral (M/L). Results: Elderly with vestibulopathy presented significantly poorer postural balance $(P<0.05)$ that active and sedentary group, with large size effect: in mean $d>0.80$. Conclusion: Elderly with vestibulopathy have poor postural balance that elderly active and sedentary. These findings have any implications for programs of rehabilitation for vestibular disorders.
\end{abstract}

Keywords: Aging; Vestibular; Postural balance; Rehabilitation.

\section{RESUMO}

Introdução: Sedentarismo e/ou a presença de qualquer doença relacionada ao sistema vestibular pode comprometer o desempenho do controle postural e aumentar o risco de quedas. Objetivo: O objetivo deste estudo foi comparar o controle postural em idosos ativos, sedentário e com vestibulopatia. Métodos: A amostra foi composta por 45 idosos separados de acordo com sua condição de saúde atual: idoso ativo, sedentário e vestibulopatia. Os testes de equilíbrio postural foram realizados em apoio bípede, com olhos abertos e as variáveis medidas pela plataforma de força foram o centro de pressão e velocidade média de oscilação postural nas direções, ântero-posterior (A/P) e médio-lateral (M/L). Resultados: Idosos com vestibulopatia apresentaram pior equilíbrio postural $(P<0.05)$ do que os idosos ativos e sedentários, com grande magnitude do tamanho de efeito, em média: $d>0,80$. Conclusão: Idosos com vestibulopatia têm pior equilíbrio postural que idosos ativos e sedentários. Estes achados têm implicações para o processo de reabilitação associado às desordens do sistema vestibular.

Palavras-chave: Envelhecimento; Vestibular; Equilíbrio postural; Reabilitação.

\footnotetext{
${ }^{1}$ PhD Studant in Program in Rehabilitation Sciences UEL/UNOPAR. Universidade Norte do Paraná (UNOPAR), Londrina, Paraná, Brazil.

2 Physical Therapist. Universidade Norte do Paraná (UNOPAR), Londrina, Paraná, Brazil.

${ }^{3}$ Master and PhD Program in Rehabilitation Sciences UEL/UNOPAR. Physical Therapy Department, Universidade Norte do Paraná (UNOPAR), Londrina, Paraná, Brazil.

Correspondng author: Viviane de Souza Pinho Costa. Marselha Street, 591, Jardim Piza. Zip code: 86041-140, Londrina, Paraná, Brazil. Phone: (43) 3371-9848 / (43) 9649 1500. E-mail: vivicosta74@gmail.com

Authors contributions: All authors participated in data collection, analysis and writing of the manuscript.

Financial support: Coordenação de Aperfeiçoamento de Pessoal de Nível Superior (CAPES) and Fundação Nacional de Desenvolvimento do Ensino Superior Particular (FUNADESP)

The authors declare no conflicts of interest.
}

Submission date 3 September 2015; Acceptance date 2 December 2015; Online publication date 15 December 2015

http://dx.doi.org/10.17784/mtprehabJournal.2015.13.330 


\section{INTRODUCTION}

The aging process is irreversible and multifactorial that included genetic and environmental factors and are associated with physiological and morphological changes in the musculoskeletal system mainly in the elderly people. ${ }^{(1)}$ All these changes contribute to the increased risk of falls among the elderly, (2) such that the postural imbalance is a major determinant for the occurrence of this event ${ }^{(3)}$ and this presents new needs for attention in public health care. ${ }^{(4)}$ Furthermore, to be sedentary or have the presence of any disease related to vestibular system also can compromise the performance of the postural control and thus, increases the risk of falls. Some studies have investigated postural control in elderly people with different health conditions, ${ }^{(5,6)}$ but few reported difference between those with vestibular disorder related to two different groups (active and sedentary elderly) based on balance parameters from a force platform measurement.

Therefore, the purpose of this study was to compare the postural control of elderly active, sedentary and with a vestibular pathology. The hypothesis was that elderly with vestibular pathology would present poorer postural control than those elderly active and sedentary.

\section{METHODS}

\section{Subjects}

Fourteen five elderly were allocated in three groups according to health condition (elderly active group - EAG, (male: 3 and female: 12 ) age: $66 \pm 5$; body mass index (BMI): 26 \pm 3 ), (elderly sedentary group - ESG, (male: 1 and female: 14 ) age: $69 \pm 4$; BMI: $28 \pm 3$ ) and (elderly with vestibulopathy group - EVG, (male: 1 and female: 14 ) age: $68 \pm 7$; BMI: $25 \neg \pm 5$ ). For classification of elderly in each group adopted the following criteria: 1) Elderly active: those who regularly practiced physical activity for a time greater than or equal to three months with the weekly frequency of at least twice per week; 2) Elderly sedentary: those who do not practice any regular physical activity for at least three months; 3) Elderly with vestibulopathy: with medical diagnosis and complementary exams by identifying the clinical picture for the so-called peripheral and central vestibulopathy.

The participants included were individuals over 60 years old, who lived physically independently according to the classification proposed by the Functional Status Spirduso (levels 3 and 4) (Spirduso, 1995); no falls in the past year and a cognitive status of $>21$ on the Mini-Mental State Examination (Hughes et al., 1996). Individuals with severe heart disease or mental limitations that would impair understanding and performance of the tests involved in the study were excluded. All subjects agreed to participate in this study and signed a written informed consent. This research project was approved by the Ethics Committee of the Universidade Norte do Paraná (PP0070/09).

\section{Procedures}

All participants were familiarized with the equipment and protocol. ${ }^{(7)}$ Balance assessment was performed with a standardized protocol: barefoot with their arms at their sides or parallel to their trunk. During testing with eyes open, the participant would look at a target (a cross) placed on a wall at eye level $2 \mathrm{~m}$ away. Three trials of $30 \mathrm{~s}$ in bipedal stance condition were computed, with $30 \mathrm{~s}$ rest intervals between each which. A landmark on the force platform was used to standardize the position of the feet during all balance conditions. ${ }^{(7)}$

Force signals were sampled at $100 \mathrm{~Hz}$ and filtered with a $35 \mathrm{~Hz}$ low-pass second-order Butterworth filter and converted into Centre of Pressure (COP) data using MATLAB routines (The Mathworks, Natick, MA). Stabilographic analysis of COP data was used to calculate [7]: $95 \%$ confidence ellipse area of COP (A-COP in $\mathrm{cm}^{2}$ ), mean velocity (VEL in $\mathrm{cm} / \mathrm{s}$ ) of COP for both anteroposterior $(\mathrm{A} / \mathrm{P})$ and mediolateral $(\mathrm{M} / \mathrm{L})$ directions. ${ }^{(8)}$ These measure were calculated from mean across balance trials.

\section{Statistical analysis}

All variables were normally distributed according to Shapiro-Wilk Test and the variance observed is homogenous according to Levene Test. The results descriptive are showed in mean values and standard deviation. One-way ANOVA was performed to determine differences among three groups (active, sedentary and vestibulopathy) on balance measures. When necessary, post hoc Tukey's test was used to identify differences between the three groups. The statistical analyses were performed with SPSS statistical software (version 20.0 for Windows) with an alpha level of 0.05 .

\section{RESULTS}

The groups were similar with regard to age and body mass index $(P>0.05)$. Significant groups differences were reported by ANOVA. Multiple comparison by Tukey tests revealed significant differences between elderly with vestibulopathy and active and sedentary groups $(P<0.05)$, as reported for all COP variables (Table 1 ). Vestibulopathy group had poor balance performance that others groups.

Table 1. Results from multiple comparison on balance measures.

\begin{tabular}{ccccc}
\hline & EAG & ESG & EVG & Anova \\
\hline $\begin{array}{c}\text { A-COP }\left(\mathrm{cm}^{2}\right) \\
\text { VEL A/P } \\
(\mathrm{cm} / \mathrm{s})\end{array}$ & $0.93 \pm 0.43$ & $1.17 \pm 1.21$ & $1.86 \pm 1.18$ & $0.048^{*}$ \\
$\begin{array}{c}\text { VEL M/L } \\
(\mathrm{cm} / \mathrm{s})\end{array}$ & $0.46 \pm 0.09$ & $0.54 \pm 0.19$ & $0.62 \pm 0.14$ & $0.021^{*}$ \\
\hline
\end{tabular}

Note: mean values with \pm Standard Deviation. Groups: Elderly active group - EAG; Elderly sedentary group - ESG; Elderly vestibulopathy group - EVG. Balance parameters: $95 \%$ confidence ellipse area of COP (A-COP in $\left.\mathrm{cm}^{2}\right)$, mean velocity (VEL in $\mathrm{cm} / \mathrm{s}$ ) of COP in anteroposterior $(\mathrm{A} / \mathrm{P})$ and mediolateral $(\mathrm{M} / \mathrm{L})$ directions. * Significant differences between groups. Tukey Post hoc revealed significant difference between elderly with vestibulopathy and other groups $(P<0.05)$. 


\section{DISCUSSION}

Elderly people with impairment in the vestibular system present a reduction in sensory information, which interfere in the automatic response mechanisms and can result in postural postural instability. ${ }^{(9)}$ These facts justify our results showing that the vestibular changes can interfere in the postural balance of the elderly, as your skills are impaired.

However, Macedo et al. ${ }^{(10)}$ demonstrated similar values of COP for patients with chronic vestibular dysfunction when compared to data from healthy elderly (sedentary) in bipedal stance. The authors explained these results by the ability of pathological group develop better the visual and somatosensory cues for maintaining balance and thus compensate for the inaccurate information from the vestibular system. ${ }^{(10,11)}$ However, these discrepancies of results between the studies could be related by differences from methodological protocol.

The static balance in elderly with vestibulopathy is worse in the sensory conditions that are more challenging. ${ }^{(12)}$ Ruwer et al. ${ }^{(12)}$ reported that complaints of tinnitus, hearing loss and in special dizziness largely affect postural balance of elderly subjects, especially the ones that do not have an active life, and that a change to perform different activities in groups have showed better postural balance in this population. Mraz et al. (13) demonstrated that physiotherapy program decrease of the range of sways and an improvement of visuomotor coordination, which improved balance control in the standing position in patients with vertigo. It was well documented in the literature that the practice of exercise promotes benefits for postural balance in elderly people. ${ }^{(14)}$ Our findings corroborate this information showing that sedentary elderly or vestibular disease has worse postural control and that the exercise can be a tool to improve this prejudice.

\section{CONCLUSION}

Elderly with vestibulopathy showed poor postural balance that elderly active and sedentary. The results of the current study have many implications for both prevention and rehabilitation programs for the elderly with disorders of vestibular system.

\section{REFERENCES}

1. Ninu P, Raghavan R. Aging and Injury: Alterations in Cellular Energetics and Organ Function. Aging Dis. 2014;5(2):101-108.

2. Horak FB. Postural orientation and equilibrium: what do we need to know about neural control of balance to prevent falls? Age Ageing. 2006;35(2):7-11.

3. Lord SR, Sherrington C, Menz HB. Falls in older people at home: risk factors and intervention strategies. Je Hum-Envir System. 2008;1:37-42.

4. Lima TJV, Arcieri RM, Garbin CAS, Moimaz SAS. Humanização na Atenção à Saúde do Idoso. Saúde Soc. São Paulo. 2010;19(4)866-877.

5. Pimentel RM, Scheicher ME. Comparação do risco de queda em idosos ativos sedentários e ativos por meio da escala de equilíbrio de Berg. FisioterPesqui. 2009;16(1):6-10.

6. Gervais T, Burling N, Krull J, Lugg C, Lung M, Straus S, et al. Understanding Approaches to Balance Assessment in Physical Therapy Practice for Elderly Inpatients of a Rehabilitation Hospital. Physiotherapy Canada 2014;66(1):6-14.

7. de Oliveira MR, da Silva RA, Dascal JB, Teixeira DC. Effect of different types of exercise on postural balance in elderly women: a randomized controlled trial. Arch Gerontol Geriatr. 2014;59(3):506-14.

8. Silva RA, Martin B, Parreira RB, Teixeira DC, Amorim CF. Age-related differences in time-limit performance and force platform-based balance measures during one-leg stance. J ElectromyogrKinesiol. 2013;23(3):6349.

9. Iwasaki S, Yamasoba T. Dizziness and Imbalance in the Elderly: Age-related Decline in the Vestibular System. Aging Dis. 2014;6(1):38-47.

10. Macedo C, Gazzola JM, Ricci NA, Doná F, Ganança FF. Influence of sensory information on static balance in older patients with vestibular disorder. Braz J Otorhinolaryngol. 2015;81(1):50-7.

11. Pedalini ME, Cruz OL, Bittar RS, Lorenzi MC, Grasel SS. Sensory organization test in elderly patients with and without vestibular dysfunction. Acta Otolaryngol. 2009;13:1-4.

12. Ruwer SL, Rossi AG, Simon LF. Balance in the elderly. Braz J Otorhinolaryngol. 2005;71(3):298-303.

13. Mraz M, Curzytek M, Mraz MA, Gawron W, Czerwosz L, Skolimowski T. Body balance in patients with systemic vertigo after rehabilitation exercise. J Physiol Pharmacol. 2007;58(5):427-36.

14. Lesinski M, Hortobágyi T, Muehlbauer T, Gollhofer A, Granacher U. Effects of Balance Training on Balance Performance in Healthy Older Adults: A Systematic Review and Meta-analysis. Sports Med. 2015;45(12):1721-38. 